\title{
Innovation and beyond: Dangers in improvised negative pressure wound therapy systems
}

Sir,

The article "Timer switch to convert suction apparatus for negative pressure wound therapy (NPWT) application" by Amarnath et al., except for the fact of devising a timer switch raises a lot of questions. ${ }^{[1]}$

NPWT in the pressure range $50-150 \mathrm{~mm} \mathrm{Hg}$ is welldocumented as an aid in improving the local wound environment aiding in faster definitive closure. Intermittent negative pressures in the range 100-125 $\mathrm{mm} \mathrm{Hg}$, and the use of foam with open pore design that permits micro- and macro-deforming strain of the cells at the foam-wound interface are accepted as the factors responsible for the growth of granulation tissue in problem wounds..$^{[2]}$

The article "Timer switch to convert suction apparatus for NPWT application" gives the impression that the improvised techniques as described are excellent. There are serious concerns regarding the assertions on the techniques adopted by them.

1. The pressures indicated on the dial of the pressure gauge of the wall suction, as well as regular ward suction units are unreliable and never calibrated. Hence, safety and delivery of the pressure range cannot be assured.

2. The regular suction units in the wards are not robust enough for continuous usage even in the intermittent mode, failing after a few days (3-5 days) with burnout of the motor or failure of the compressor. No information is given regarding the model of the suction machine used or the observed failure rate of the machine.

3. While polyvinyl alcohol (PVA) sponges are safe as a biomaterial, the same cannot be used as a case for the safety of commercially available PVA sponge used for industrial applications. Will the PVA sponge be made 'medical grade' by repeated washing? Moreover, the description of the washing process itself indicates eluents at room temperature. There is no proof that at body temperature and the pressure applied, as well as during autoclave cycle further degradation leaching 
out and transmigration of toxic material cannot occur. On reading the US patent application referred to it is very clear that there are processes with more toxic ingredients, used for commercial production of PVA sponges. The patent is specifically for a process of manufacturing for obtaining one type of medical grade PVA sponge. It does not in any way support the assertion made by the authors. ${ }^{[3]}$

4. Moreover, how was it ensured that the sponges were PVA sponges rather than polyvinyl chloride or polyurethane sponges? There is high variability in the material, as well as the quality of the commercial sponges, which the traders are unaware of.

5. Even with the use of United States Food and Drug Administration (US FDA) approved apparatus, the risk of serious complications was known. This had forced the US FDA to bring out a Public health notification on Serious Complications Associated with NPWT Systems. ${ }^{[4,5]}$ The risks will be compounded with the use of non-medical grade material, as was used in the article 'Timer switch to convert suction apparatus for NPWT application'.[1]

6. Due to the different factors as pointed out, in the event of a limb-threatening/life-threatening adverse event we will be open for damaging litigation with no defence. Then the perceived cost benefit will transform to become a huge liability on the surgeon.

However, the innovative idea of the timer switch is to be welcomed as the first small step towards a less costly NPWT system. For this to be achieved, we need, in addition, a more robust suction machine than currently available, a pressure gauge with good calibration and periodic recalibration, and medical grade PVA sponge certified by Drugs Controller of India.

\section{Financial support and sponsorship}

Nil.

\section{Conflicts of interest}

There are no conflicts of interest.

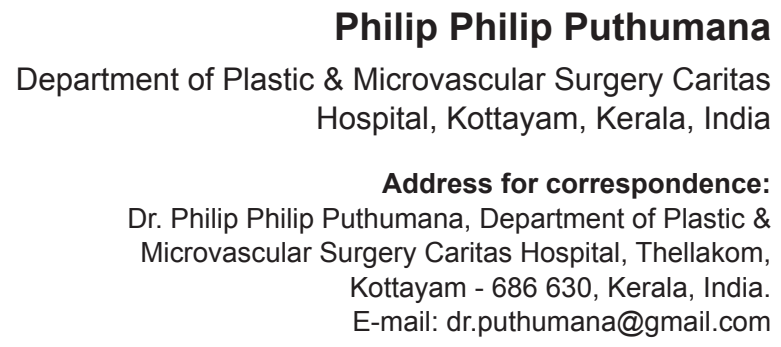

Indian Journal of Plastic Surgery May-August 2015 Vol 48 Issue 2

\section{REFERENCES}

1. Amarnath S, Reddy MR, Rao $\mathrm{CH}$, Surath HV. Timer switch to convert suction apparatus for negative pressure wound therapy application. Indian J Plast Surg 2014;47:412-7.

2. Orgill DP, Bayer LR. Update on negative-pressure wound therapy. Plast Reconstr Surg 2011;127 Suppl 1:105S-15S.

3. Patent US4098728 Medical Surgical Sponge and Method of Making Same, Google Patents. Available from: http:// www.google.co.in/patents/US4098728. [Last accessed on 2015 Jan 17].

4. FDA Safety Communication: UPDATE on Serious Complications Associated with Negative Pressure Wound Therapy Systems. Available from: http://www.fda.gov/MedicalDevices/Safety/ AlertsandNotices/ucm244211.htm. [Last accessed on 2015 July 17].

5. The FDA Preliminary Public Health Notification: Serious ComplicationsAssociated with Negative Pressure Wound Therapy Systems. Available from: http://www.fda.gov/MedicalDevices/ Safety/AlertsandNotices/PublicHealthNotifications/ucm190658. htm. [Last accessed on 2015 July 17].

This is an open access article distributed under the terms of the Creative Commons Attribution-NonCommercial-ShareAlike 3.0 License, which allows others to remix, tweak, and build upon the work non-commercially, as long as the author is credited and the new creations are licensed under the identical terms.

\begin{tabular}{|l|l|}
\hline \multicolumn{2}{|c|}{ Access this article online } \\
\hline Quick Response Code: & Website: \\
\hline & www.ijps.org \\
\hline & DOI: \\
\hline
\end{tabular}

How to cite this article: Philip PP. Innovation and beyond: Dangers in improvised negative pressure wound therapy systems. Indian J Plast Surg 2015;48:217-8. 